
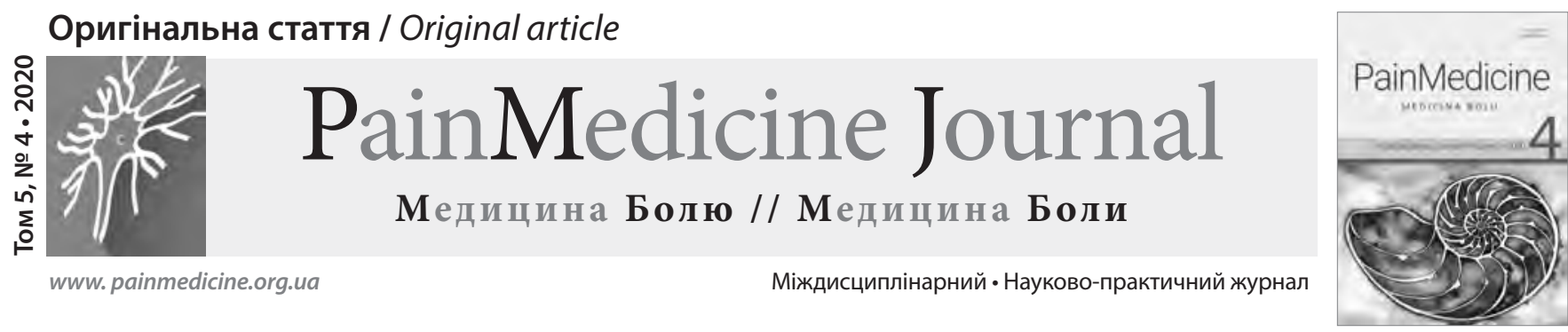

DOI: 10.31636/pmjua.v5i4.4

\title{
Ultrasound-guided Quadratus Lumborum Block versus caudal block for postoperative analgesia in children undergoing acute appendicitis: a comparative study
}

\author{
${ }^{1}$ Dmytriiev D. V., ${ }^{2}$ Glazov Ye. O., ${ }^{1}$ Zaletskyi B. V., ${ }^{1}$ Dmytriieva K. Y. \\ ${ }^{1}$ National Pirogov Memorial Medical University, Vinnytsia \\ ${ }^{2}$ Regional Children's Clinical Hospital, Odessa
}

\begin{abstract}
Background: ultrasound (US)-guided Quadratus Lumborum Block(QLB) is an effective technique in providing analgesia for abdominal surgery. This study was designed to evaluate the efficacy of a US-guided Quadratus Lumborum Block (QLB) compare it with a caudal block in children after acute appendicitis.

Patients and methods. Forty eight (48)ASA 1-2,1-5-year-old children scheduled for elective acute appendicites were studied. All patients received general anesthesia; sevoflurane was used for induction and maintenance of anesthesia and laryngeal mask airway (LMA) was used to secure the airway. After securing an intravenous cannula, patients were randomized to a US-guided Quadratus Lumborum Block $(Q L B)(n=24)$ (group Q) using $0.5 \mathrm{ml} / \mathrm{kg}$ of $0.25 \%$ bupivacaine, injected on the same side of surgery, and group C received a caudal block using $1 \mathrm{ml} / \mathrm{kg}$ of $0.2 \%$ bupivacaine $(n=24)$. Surgery was allowed 15 min after administration of the block. Block failure was considered in case of gross movement or more than $20 \%$ change in heart rate and/or ABP persisting more than 1 min after skin incision. Any adverse events were recorded. After surgery, patients remained for $4 \mathrm{~h}$ in the recovery room. Postoperative analgesia was evaluated using Children and Infants Postoperative Pain Scale (CHIPPS). An anesthesiologist, who was not part of the study team, evaluated the need for rescue analgesia in the intraoperative and postoperative period and a recovery nurse collected the data. If the CHIPPS score was greater than 4, a rescue analgesia of $20 \mathrm{mg} / \mathrm{kg}$ acetaminophen was administered. Results. No difference was found in hemodynamics in both groups. Also, intraoperative fentanyl consumption was not different and no rescue analgesia was required in the postanesthesia care unit.
\end{abstract}

Conclusion. US-guided Quadratus Lumborum Block $(Q L B)$ is as effective as caudal block in providing immediate postoperative analgesia in acute appendicitis.

Key words: caudal block, acute appendicitis, US-guided Quadratus Lumborum Block(QLB)

\section{Introduction}

Caudal epidural analgesia is the most common regional technique performed in children. It has been used for many years as a sole anesthetic, adjuvant to a general anesthesia, and to provide postoperative analgesia for subumbilical procedures; it is the preferred technique in groin surgery [1]. The caudal approach to the epidural space is preferred in children because of the ease of access through the sacrococcygeal ligament and the potential decreased risk of injury to neural structures at this level compared with access at the lumbar and thoracic 
levels [2]. Quadratuslumborum (QL) block has been described by Blanco and used as an analgesic for abdominoplasties (unpublished) [6]. The radiological study on posterior approach of Transversus Abdominis Plane block (now called QL block) in volunteers has shown the spread of the dye and local anaesthetics from T4-L1 [7]. The Quadratus Lumborum Block (QLB) is a new regional anesthesia technique that provides analgesia after abdominal surgery [9]. It can be performed using a landmark technique through the lumbar triangle or with ultrasound (US) guidance. As safe and effective, regional anesthesia requires local anesthetics to be placed in close proximity to target nerves without injury to target nerves or adjacent structures. The use of US in regional anesthesia in children was shown to improve sensory and motor block, and might reduce the risk of complications $[6,10]$. Few studies have described the use of Quadratus Lumborum Block (QLB) for postoperative analgesia in children $[9,11]$; however, it has not been compared with the most commonly used technique, caudal block, as yet. The aim of this study was to evaluate the analgesic efficacy of a US-guided Quadratus Lumborum Block (QLB) and to compare it with a caudal block in children undergoing acute appendicitis.

\section{Patients and Methods}

After obtaining approval of the Hospital Ethics Committee (Vinnytsia regional children hospital, Vinnytsia, Ukraine], 44 ASA I-II patients aged 1-5 years scheduled for elective outpatient acute appendicitis were enrolled. A written informed consent was obtained from the father or the legal guardian of the patient. Patients were excluded if there was parental refusal, any contraindication to a caudal block, for example, bleeding disorders, local site infection, and a history of relevant drug allergy. All patients received general anesthesia; sevoflurane was used for the induction and maintenance of anesthesia (together with $\mathrm{NO}_{2} 60 \%$ in $\mathrm{O}_{2}$ ) and LMA was used to secure the airway. Standard monitoring (ECG, $\mathrm{ABP}, \mathrm{SPO}_{2}$, and end-tidal $\mathrm{CO}_{2}$ ) was applied to all patients and the monitoring results were recorded every $5 \mathrm{~min}$. After securing an intravenous cannula, patients were randomized, by computer-generated random tables and the sealed-envelope technique, to receive either a US-guided Quadratus Lumborum block (group Q) or a caudal block (group C). In group Q, patients were placed in a supine position and a high-frequency $3.5-12 \mathrm{MHz}$, hockey-stick transducer, connected to a Ezono 4000 portable US machine (Ezono, Germany), was used. The probe was initially positioned perpendicular to the anterior abdominal wall to visualize the rectus abdominis muscle at the level of the umbilicus. The patient was in the supine position. A high-frequency linear probe was attached in the area of the triangle of Petit until the QL was confirmed. The needle tip was placed at the anterolateral border of the QL at its junction of QL with transversalis fascia, and the local anesthetic was injected. We confirmed via ultrasound that the local anesthetic is deep to the transversus abdominis aponeurosis (Fig. 1).

After skin disinfection, a 22-G 50-mm needle with an injection line (Stimuplex A, B. Braun Melsungen AG, Berlin, Germany) was used. Once the tip of the needle was placed in the space between the internal oblique abdomi-

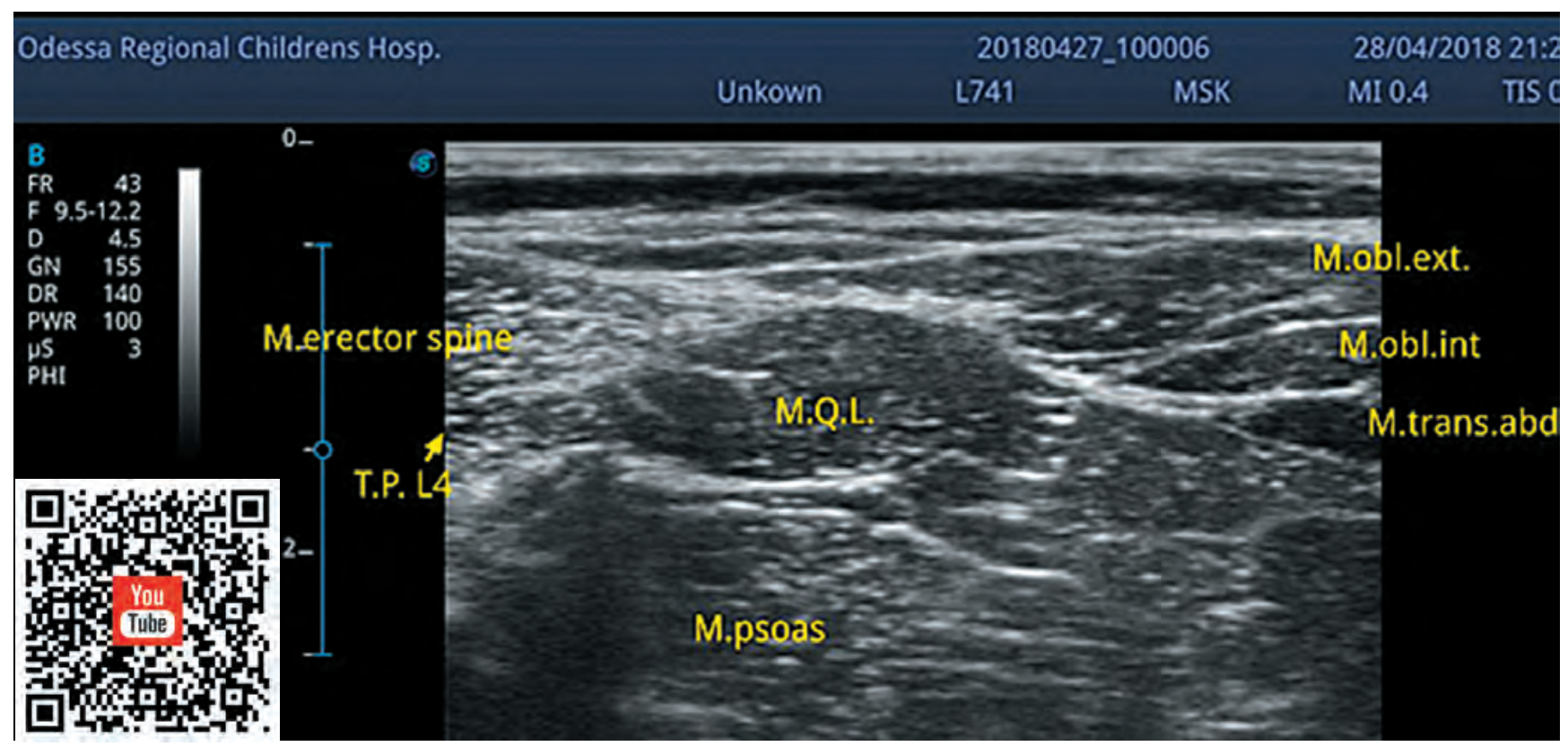

Fig. 1. Ultrasound images of subcostal QL block. Preinjection and postinjection. MQL: quadratus lumborum, T.P. L4 - transversus processus L4 (level), M. psoas: psoas muscle. 
nal muscle and transversus abdominis muscle in the same operative site, using an 'in-plane' technique to visualize the entire needle, and after negative aspiration, bupivacaine $0.5 \mathrm{ml} / \mathrm{kg} 0.25 \%$ was injected. An injection was considered successful when an echolucent lens shape appeared between the two muscles.

In group $\mathrm{C}$, patients were placed in the left lateral position and a caudal block was administered under aseptic conditions using $1 \mathrm{ml} / \mathrm{kg} 0.2 \%$ bupivacaine. The maximum dose of $2 \mathrm{mg} / \mathrm{kg}$ bupivacaine was not exceeded in both groups. Both QLB and caudal techniques were performed by the same anesthetist (first author) who was not involved in patient management after performing the block. Patients were managed by another anesthetist who was unaware of the technique used. Successful blockade was defined by the absence of gross movement or a significant $(>20 \%)$ change in heart rate (HR) and/ or ABP on application of skin incision, which was allowed 15 min after performing the technique. Signs of inadequate analgesia (gross movement or $>20 \%$ change in $\mathrm{HR}$ and/or $\mathrm{ABP}$ ) persisting more than $1 \mathrm{~min}$ after skin incision were managed by increasing the sevoflurane concentration and fentanyl $1 \mathrm{mg} / \mathrm{kg}$ and the block was considered a failure (those patients were administered paracetamol $20 \mathrm{mg} / \mathrm{kg}$ per rectum immediately after the completion of surgery). Fentanyl was repeated as clinically indicated and the total number of intraoperative fentanyl doses administered was recorded. After surgery, patients were observed for $4 \mathrm{~h}$ in the postanesthesia recovery unit by recovery room nurses who were blinded to the technique used. Postoperative analgesia was evaluated using the Children and Infants Postoperative Pain Scale (CHIPPS) [5]. CHIPPS is a well-validated and reliable scale in determining postoperative analgesia demand in children. It consists of five items (crying, facial expression, posture of the trunk, posture of the legs, and motor restless) with a score of $0-2$ for each item. Values between 0 and 3 indicate a pain-free state and 4 points or more identify the increasing need for supplemental analgesia. Motor weakness was determined using a simple three-point scale ( 0 , no movements; 1 , possible to move the legs; and 2, able to stand) [9]. CHIPPS and motor weakness were measured every $30 \mathrm{~min}$ for $4 \mathrm{~h}$. If the CHIPPS score was greater than 4, rescue analgesia of $20 \mathrm{mg} / \mathrm{kg}$ rectal acetaminophen was administered. The duration of analgesia, defined as the time from termination of anesthesia to the first analgesic administration, was also recorded. If no rectal acetaminophen was necessary within $4 \mathrm{~h}$, the duration of analgesia was counted as $4 \mathrm{~h}$. The sites of injection of the QLB block and the caudal area were inspected to detect complications such as hematomas. Any adverse events were also recorded. Patients were discharged home $4 \mathrm{~h}$ postoperatively ac- cording to the study protocol. Full instructions were provided together with the postoperative medications. Home analgesia was administered in the form of a suppository of acetaminophen $15 \mathrm{mg} / \mathrm{kg} \mathrm{4-6} \mathrm{h}$; the total dose should not exceed $60 \mathrm{mg} / \mathrm{kg}$ in $24 \mathrm{~h}$. The primary outcome was the proportion of patients who required rescue analgesia in the recovery room. The secondary outcomes included pain score in the recovery room, time to rescue analgesia, and number of unplanned admissions.

\section{Statistical methods}

The statistical test used was the two-sided Z-test with pooled variance. The significance level of the test was set at 0.05 . Twenty for (24) patients per group were included to replace any dropouts. The collected data were coded, tabulated, and statistically analyzed using the SPSS program (Statistical Package for Social Sciences) software version 10.0 (SPSS Inc., Chicago, Illinois, USA). Data were expressed as mean values $\pm \mathrm{SD}$ for numerical parametric data, median (range) for nonparametric data, and $\mathrm{n}(\%)$ for categorical data. An independent t-test was used in cases of two independent groups with parametric data and a paired t-test was used in cases of two dependent groups with parametric data. The Mann - Whitney U-test was used for nonparametric data and the c2-test for discrete (categorical) variables, with $\mathrm{P}$ values less than 0.05 considered statistically significant.

\section{Results}

Forty patients who underwent elective outpatient unilateral open inguinal herniotomy were included in this study. Abdominal muscles, the needle, and the spread of the local anesthetic could be observed clearly in all patients in group Q and the caudal block was performed successfully in all patients in group C. No case of blood aspiration was recorded during the technique in group Q. However, one patient in group $\mathrm{C}$ received blood aspiration and the trial was repeated twice until the caudal injection was administered satisfactorily. No other local or systemic complications related to the technique of regional anesthesia or surgeries were reported. The groups did not differ with respect to age, weight, sex, duration of surgery, and duration of anesthesia (Table 1).

One patient in group $\mathrm{Q}$ showed signs of block failure (HR and/or ABP $>20 \%$ of the baseline for more than $1 \mathrm{~min}$ ) and was excluded from the study. The block was considered successful for the rest of the patients and no intraoperative fentanyl was used (Table 2) shows the hemodynamic variables in both groups.

No rescue analgesia was required in the postanesthesia recovery unit for both groups. The CHIPPS score showed a tendency to be higher in group Q compared 
Table 1. Demographic and operative data in both groups

\begin{tabular}{lcccc}
\hline Variable & & Croup Q & Croup C & P value \\
\hline Age (years) & $3.1 \pm 0.8$ & $3.3 \pm 0.7$ & 0.64 \\
\hline Sex & $\mathrm{M}$ & 10 & 11 & 0.70 \\
\cline { 2 - 4 } & $\mathrm{F}$ & 14 & 13 & 0.52 \\
\hline Weigt (kg) & $15.4 \pm 1.2$ & $16.0 \pm 1.1$ & 0.24 \\
\hline Duration of surgery (min) & $35.4 \pm 3.2$ & $36.0 \pm 4.1$ & 0.27 \\
\hline Duration of anesthesia (min) & $40.2 \pm 3.2$ & $38.8 \pm 4.02$ & \\
\hline
\end{tabular}

Table 2. Heart rate and mean arterial pressure in both groups

\begin{tabular}{lccc}
\hline Parameters & Croup Q & Croup C & P value \\
\hline Heart rate (before) & $123.1 \pm 2.8$ & $124.8 \pm 2.4$ & $0.32 \&$ \\
\hline Heart rate (after) & $112.2 \pm 2.4$ & $116.2 \pm 21.1$ & $0.64 \&$ \\
\hline Mean arterial pressure (before) & $0.32^{*}$ & $0.24^{*}$ & \\
\hline Mean arterial pressure (after) & $85.9 \pm 3.2$ & $86.4 \pm 2.8$ & $0.28 \&$ \\
\hline & $84.1 \pm 2.6$ & $87.2 \pm 4.2$ & $0.36 \&$ \\
\hline
\end{tabular}

Data were expressed as mean $\pm \mathrm{SD}$

* Comparison between before and after skin incision

\& Comparison between the two groups

$\mathrm{p} \geq 0.05$ - was considered statistically nonsignificant

with group C; however, the difference was not statistically significant (Table 3 ).

No signs of motor blockade could be observed after the first postoperative hour in any of the patients. During the first postoperative hour, one patient in group $\mathrm{C}$ had a motor blockade score of 1 , whereas none of the patients in group $\mathrm{Q}$ had any sign of motor blockade. All patients were discharged home $4 \mathrm{~h}$ postoperatively according to the study protocol and nonrequirement of hospital admission. No adverse events were noted during the observation period in the postanesthesia recovery unit.

Discussion. Regional anesthesia attenuates the stress response to surgery and produces excellent postoperative analgesia in infants and children. Caudal anesthesia is the oldest and still most commonly used technique in children. It is recommended mainly for surgical procedures below

Table 3. Children and Infants Postoperative Pain Scale score in the first $4 \mathrm{~h}$ postoperatively

\begin{tabular}{lccc}
\hline Postoperative period & Croup Q & Croup C & P value \\
\hline $30(\min )$ & $0.5(0-1)$ & $1(0-1)$ & 0.70 \\
\hline $60(\min )$ & $0.5(0-1)$ & $1(0-1)$ & 0.44 \\
\hline $90(\min )$ & $1(0-1)$ & $1(0-1)$ & 0.24 \\
\hline $120(\min )$ & $1(0-1)$ & $1(0-1)$ & 0.28 \\
\hline $180(\min )$ & $1(0-1)$ & $1.5(1-2)$ & 0.16 \\
\hline $240(\min )$ & $2(0-3)$ & $2(1-3)$ & 0.36 \\
\hline
\end{tabular}

Data were expressed as median and range; $\mathrm{p} \geq 0.05$ - was considered statistically nonsignificant 
the umbilicus, including inguinal hernia repair, urinary, and digestive tract surgeries, and orthopedic procedures on the lower extremities [10]. Truncal blocks have a place within multimodal analgesia techniques in abdominal surgery. The quadratus lumborum block is a new abdominal truncal block used for somatic analgesia of both the upper and lower abdomen. In this prospective, double-blind, randomized study, we aimed to compare quadratus lumborum block and transversus abdominis plane block in pediatric patients undergoing lower abdominal surgery [12]. US allows the precisely visualization of the blocking needle (the entire needle or its tip depending on the use of the inplane or the out-of-plane technique), the anatomy (the three abdominal muscle layers, the peritoneum, and intraperitoneal visceral structures), and also the real-time assessment of the local anesthetic distribution characterized by an anechoic image between the internal oblique and the transversus abdominis muscles [11]. Although the preliminary literature in infants and children suggests that the QLB block provides effective analgesia following various umbilical and lower abdominal procedures, including laparoscopy [12], few studies have been carried out showing its analgesia efficacy in hernia repair surgery [5-8], and none has compared it with the most commonly used regional technique in children: the caudal block.

The results of this study show that a US-guided QL block is as effective as a caudal block in providing intraoperative and postoperative analgesia for unilateral day-surgery hernia repair in children. Both techniques (QLB block and caudal block) were successful in providing effective intraoperative and postoperative analgesia for the study patients (except for one patient in group Q). No intraoperative fentanyl was used and no postoperative rescue analgesia was required during the study period (4 $\mathrm{h}$ postoperatively). In agreement with our results, QLB block provided effective analgesia in a postoperative analgesia [8]. All patients recorded postoperative pain scores of $0-2$ and seven patients required no postoperative opiates; one patient received intravenous morphine for the treatment of emergence agitation. Three patients showed signs of intraoperative incomplete analgesia and were treated with fentanyl $(<0.5 \mathrm{mg} / \mathrm{kg})$. Since the first description of the QL block about 10 years ago $[1,10]$, several QL blocks have been reported [1, 7-12]. The QL block cannot generate anesthesia without additional procedures. We do not know whether each QL block relieves complete somatic and visceral pain; hence we recommended QL block as an add-on block to reduce the requirement of general anesthetic intraoperatively or it could be used as the main component of multimodal analgesia postoperatively. Though the anterior and posterior QL blocks may spread the local anesthetic into the paravertebral space, the full scope of spread from each of the four blocks is not clear $[3,6]$. To further understand the mechanisms of the several QL blocks, we must perform dye injection study simultaneously using each approach in many soft embalmed cadavers and assess the spread using multiple modalities. Variable volumes of local anesthetic in regard to each QL block were reported. We are unsure regarding the adequate volume needed to accomplish the block. However, considering previous reports $[9,13]$, at least $20 \mathrm{ml}$ of the local anesthetic at one site may be required. Because of the large volume, it is important to confirm the safety of the block to avoid LAST. Murouchi et al. measured the local anesthetic concentration after the intramuscular QL block [11].

The short postoperative pain assessment time, $4 \mathrm{~h}$, is a limitation in this study and should have been followed by telephone calls; however, because of cultural reasons, this could not be done. The available limited literature and experiences demonstrate that QL block has the potential to produce sensory blockade and analgesia along lower thoracic and lumbar regions and can be an alternative analgesic modality for selected abdominal surgeries. In addition to the characteristics of a TAP block, QL blocks have the potential to provide some visceral analgesia, considering its spread to the paravertebral space. Well-designed large studies are needed in the future to prove the efficacy and potential of this block.

\section{Conclusion}

The QL block is an effective analgesic tool for abdominal surgery and perhaps lower extremity. However, the best approach needs further validation and should be tailored to fit specific surgery whenever possible. Therefore, this review aims to make clear criteria to assess the performance of each QL block in comprehensive aspects, which facilitates future study design, provides the most updated knowledge, and contributes to the advances of techniques in deep regional blocks. A US-guided QL block is as effective as a caudal block in providing intraoperative and postoperative analgesia in day-case open inguinal hernia repair in children.

\section{References}

1. Ahmed AA, Rayan AA. Ultrasound-guided transversus abdominis plane block versus caudal block for postoperative analgesia in children undergoing unilateral open inguinal herniotomy: A comparative study. Ain-Shams Journal of Anaesthesiology. 2016 Apr $1 ; 9(2): 284$.

2. Silvani P, Camporesi A, Agostino MR, Salvo I. Caudal anesthesia in pediatrics: an update. Minerva anestesiologica. 2006 Jun;72(6):453.

3. McDonnell JG, ODonnell B, Curley G, Heffernan A, Power C, Laffey JG. The Analgesic Efficacy of Transversus Abdominis Plane Block After Abdominal Surgery: A Prospective Randomized Controlled Trial. Anesthesia \& Analgesia [Internet]. Ovid Technologies 
(Wolters Kluwer Health); 2007 Jan;104(1):193-7. Available from https://doi.org/10.1213/01.ane.0000250223.49963.0f

4. Marhofer P, Sitzwohl C, Greher M, Kapral S. Ultrasound guidance for infraclavicular brachial plexus anaesthesia in children. Anaesthesia [Internet]. Wiley; 2004 Jul;59(7):642-6. Available from: https://doi.org/10.1111/j.1365-2044.2004.03669.x

5. Battner W, Finke W. Analysis of behavioural and physiological parameters for the assessment of postoperative analgesic demand in newborns, infants and young children: a comprehensive report on seven consecutive studies. Pediatric Anesthesia [Internet]. Wiley; 2000 May;10(3):303-18. Available from: https://doi. org/10.1046/j.1460-9592.2000.00530.x

6. Willard FH, Vleeming A, Schuenke MD, Danneels L, Schleip R. The thoracolumbar fascia: anatomy, function and clinical considerations. Journal of Anatomy [Internet]. Wiley; 2012 May 27;221 (6):507-36. Available from: https://doi.org/10.1111/j.1469-7580. 2012.01511.x

7. El-Boghdadly K, Elsharkawy H, Short A, Chin KJ. Quadratus Lumborum Block Nomenclature and Anatomical Considerations. Regional Anesthesia and Pain Medicine [Internet]. BMJ; 2016;41(4):548-9. Available from: https://doi.org/10.1097/aap.0000000000000411

8. Elsharkawy H. Quadratus lumborum block with paramedian sagittal oblique (subcostal) approach. Anaesthesia [Internet]. Wiley; 2016 Jan 11;71(2):241-2. Available from: https://doi.org/10.1111/ anae. 13371
9. Blanco R, Ansari T, Riad W, Shetty N. Quadratus Lumborum Block Versus Transversus Abdominis Plane Block for Postoperative Pain After Cesarean Delivery. Regional Anesthesia and Pain Medicine [Internet]. BMJ; 2016;41(6):757-62. Available from: https://doi. org/10.1097/aap.0000000000000495

10. Lin J-A, Lu H-T. A convenient alternative for monitoring opening pressure during multiple needle redirection. British Journal of Anaesthesia [Internet]. Elsevier BV; 2014 Apr;112(4):771-2. Available from: https://doi.org/10.1093/bja/aeu083

11. Lin J-A. Importance of half-the-air pressure test in Shamrock lumbar plexus block. European Journal of Anaesthesiology [Internet] Ovid Technologies (Wolters Kluwer Health); 2016 Oct;33(10):784. Available from: https://doi.org/10.1097/eja.00 00000000000465

12. Lin J-A, Chuang T-Y, Yao H-Y, Yang S-F, Tai Y-T. Ultrasound standard of peripheral nerve block for shoulder arthroscopy: a single-penetration double-injection approach targeting the superior trunk and supraclavicular nerve in the lateral decubitus position. British Journal of Anaesthesia [Internet]. Elsevier BV; 2015 Dec;115(6):932-4. Available from: https://doi.org/10.1093/bja/ aev384

13. Baidya DK, Maitra S, Arora MK, Agarwal A. Quadratus lumborum block: an effective method of perioperative analgesia in children undergoing pyeloplasty. Journal of Clinical Anesthesia [Internet]. Elsevier BV; 2015 Dec;27(8):694-6. Available from: https://doi. org/10.1016/j.jclinane.2015.05.006

\title{
Ультразвук-контрольована блокада Quadratus Lumborum у порівнянні 3 каудальною блокадою для післяопера-
} ційного знеболення у дітей, які перенесли гострий апендицит: порівняльне дослідження

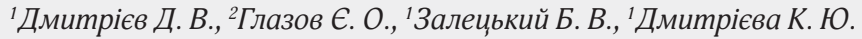

${ }^{1}$ Вінницький національний медичний університет ім. М. І. Пирогова

²Одеська обласна дитяча клінічна лікарня

Анотація. Передумови. Ультразвуково(УЗ)-контрольована блокада Quadratus Lumborum Block (QLB) - ефективна методика забезпечення знеболення при операціях на черевній порожнині. Це дослідження було проведене для оцінки ефективності блокади Quadratus Lumborum Block (QLB) під контролем ультразвуку та порівняння його з каудальною блокадою при гострому апендицитті у дітей.

Пацієнти та методи. Було вивчено сорок вісім (48) дітей АSА 1-2, 1-5-річного віку, з діагнозом гострого апендициту та потребою в оперативному втручанні. Усі пацієнти отримували загальний наркоз; севофлуран використовували для індукціі та підтримки анестезії, а ларингіальну маску використовували для захисту дихальних шляхів. Після встановлення внутрішньовенної канюлі пацієнтти були рандомізовані у дві групи: блокади Quadratus Lumborum Block (QLB) niд контролем У3 (n = 24) (група Q) з використанням 0,5 мл/кг 0,25\% бупівакаїну, введеного в однойменну сторону оперативного втручання, та група C, що отримала каудальну блокаду з використанням 1 мл/кг 0,2\% бупівакаїну $(n=24)$. Операція була дозволена через 15 хв після введення анестетику. Недостатність дії блокади розглядали у разі виникнення значного руху або зміни частоти серцевих скорочень більше ніж на 20\% та/або АТ, щз зберігається більше 1 хв після розрізу шкіри. Будь-які несприятливі діі реєструвались. Після хірургічного втручання пацієнти залишались на 4 години в кімнаті для відновлення. Післяопераційну аналгезію оцінювали за допомогою шкали післяопераційного болю у дітей та немовлят (CHIPPS). Анестезіолог, який не був частиною дослідницької групи, оцінив необхідність проведення додаткового знеболення в інтраопераційному та післяопераційному періоді, медсестра у кімнаті відновлення збирала дані. Якщо оцінка CHIPPS була більшою за 4, вводили додаткове знеболення 20 мг/ка ацетамінофену.

Результати. Різниці в гемодинаміці в обох групах не виявлено. Крім того, інтраопераційні витрати фентанілу не відрізнялись в обох групах, у відділенні післяанестезіологічної допомоги діти не потребували додаткового знеболювання.

Висновок. Quadratus Lumborum Block (QLB) під контролем ультразвуку настільки же ефективна, як каудальна блокада, для негайного післяопераційного знеболення при гострому апендициті.

Ключові слова: каудальна блокада, гострий апендицит, блокада Quadratus Lumborum Block (QLB) під контролем ультразвуку 
Ультразвук-контролированная блокада Quadratus Lumborum в сравнении с каудальной блокадой для послеоперационного обезболивания у детей, которые перенесли острый аппендицит: сравнительное исследование

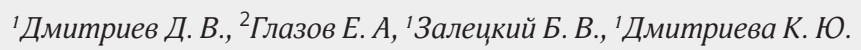

${ }^{1}$ Винницикий нацииональный медицинский университет им. Н. И. Пирогова

²Одесская областная детская клиническая больница

Резюме. Предпосылки. Ультразвук (УЗ)-контролированная блокада Quadratus Lumborum Block(QLB) - эффективная методика обеспечения обезболивания при операциях на брюшной полости. Это исследование было проведено для оценки эффективности блокады Quadratus Lumborum Block (QLB) под контролем ультразвука и сравнения его с каудальной блокадой при остром аппендиците у детей.

Пациенты и методы. Было изучено сорок восемь (48) детей ASA 1-2, 1-5-летнего возраста, с диагнозом острого аппендицุита и потребностью в оперативном вмешательстве. Все пациенты получали общий наркоз; севофлуран использовали для индукции и поддержсания анестезии, а ларингеальную маску использовали для защитты дыхательных путей. После установки внутривенной канюли пациенты были рандомизированы в две группы: блокады Quadratus Lumborum Block(QLB) под контролем УЗ $(n=24)$ (группа Q) с использованием 0,5 мл/кг 0,25\% бупивакаина, введенного в одноименную сторону оперативного вмешательства, и группу C, получивших каудальную блокаду с использованием 1 мл/ка 0,2\% бупивакаина (n=24). Операция была разрешена через 15 мин после введения анестетика. Недостаточность действия блокады рассматривали в случае возникновения значительного движения или изменения частоты сердечных сокращений более чем на $20 \%$ и/или АД, сохранявщихся более 1 мин после разреза кожи. Любые неблагоприятные воздействия регистрировались. После хирургического вмешательства пациенты оставались на 4 часа в комнате для восстановления. Послеоперационную анальгезию оценивали с помощью шкалы послеоперациионной боли у детей и младенцев (СНIPPS). Анестезиолог, который не был частью исследовательской группы, оценил необходимость проведения дополнительного обезболивания в интраоперационном и послеоперационном периоде, медсестра в комнате восстановления собирала данные. Если оценка CHIPPS была больще 4, вводили дополнительное обезболивание 20 мг/кг ацетаминофена.

Результаты. Разницы в гемодинамике в обеих группах не выявлено. Кроме того, интраоперационные расходы фентанила не отличались в обеих группах, в отделении послеанестезиологической помощзи дети не нуждались в дополнительном обезболивании.

Bывод. Quadratus Lumborum Block (QLB) под контролем ультразвука столь же эффективна, как каудальная блокада, для немедленного послеоперациионного обезболивания при остром аппендициите.

Ключевые слова: каудальная блокада, острый аппендициит, блокада Quadratus Lumborum Block(QLB) под контролем ультразвука 